\title{
S. Paulo e a Catedral (*)
}

\section{S. Soares de Faria}

Caminhando a estrada que o devia conduzir a Damasco, na sua ânsia de perseguir os cristãos, SAUL caminhava tangido por misteriosa intuição. Algo de divino envolvia o seu pensamento; sua alma pressentia a revelação, que se aproximava, e todo seu sêr se agitava na doce visão de um magnífico destino. Eis, senão quando no enlevo dessa miragem, que o empolgava, fere-o o ráio, que o fulmina, e a imprecação divina, que o conturba; e seus ouvidos recebem a interrogação, que o dexia perplexo, a recriminação, que o desperta: Por que me perseguis?

Levanta os olhos e vê realmente a Cristo, que não conhecera. A ạarição divina o comove e transfigura, e o seu espirito se dobra, - ante a demonstração magnifica da divindade de Jesus. Sua alma inteira-se da Verdade - seu coração transborda de estranhas alegrias; sua inteligência recebe os clarões que espancam os erros, que a obscureciam, e todo ele, - por um milagre da onipotência divina, - se converte, inteiramente, ao credo que até então combatia. $\mathrm{E}$ ali mesmo, antes que a aparição se desfizesse, recebe a fôrça imensa, que Jesus lhe confiava, para fazer dele o maior dos defensores de sua palavra e de sua obra. Todas as suas qualidades o talhavam para a investidura, que por tal fórma recebia. Inteligência viva e vontade dominadora. Coragem e intrepidez, audácia e resignação, ardoroso no ataque, paciente nos revezes, calmo e tranquilo no marti-

(*) Discurso pronunciado, a 25 de janeiro de 1940 , na Rádio Excelsior, por ocasião da Semana da Catedral e a convite da comissão encarregada. 
rio, persistente nos seus desígnios, - SAUL, que se fizera Paulo, o santo cujas virtudes hoje celebramos, foi o espirito que desenvolveu a doutrina divina. Si PEDRo foi a rocha sobre a qual Jesus Cristo edificou a sua Igreja, São Paulo foi a alma, - que a tornou viva - e vigorosa, dando corpo à palavra do Senhor, difundindo-a, propagando-a, discutindo-a com os sacerdotes da religião, que abjurara, com os filósofos na ágora de Atenas, fazendo prosélitos em Roma, indo da Iliria à Espanha, impondo a sua vontade aos timidos, sempre pronto a dar o testemunho o mais decidido da sua fé, como aqueles personagens, que ele mesmo nos descreve, num esplêndido capítulo da sua epístola aos Hebreus, que, lapidados, estraçalhados pelo ferro, partidos em pedaços, ocultando-se nos desertos e nas cavernas, hi omnes testimonio probati. E deu sempre esse testemunho, indiferente à dureza das perseguições, e a crueldade dos martírios. $\mathrm{E}$ foi martirisado, e glorificado, e santificado. Tal o apóstolo, que admiramos, o soldado de Cristo, que enaltecemos, o santo, a que hoje entoamos os cânticos de nossa fé. Com ele, memoramos o nascimento da cidade, que por ocultos e impenetraveis desígnios do Senhor Supremo, surgiu no dia a ele consagrado. Não foi obra do acasso, mas dom da graça divina. E sob o seu patrocínio, as qualidades marcantes do Santo reproduziram-se nos filhos da cidade, que, nesta planura, edificaram os missionários de Loyola. Sob a sua proteção, o núcleo insignificante, desenvolvendose em torno do colégio, espraiando-se pelas colinas circumjacentes, dilatando-se pelos vales, transpondo os montes, desbravando o mistério dos sertões, dilatando e protraindo as lindes iniciais, vencendo e dominando os nativos, transformou-se na maravilha desta metrópole, que é o nosso encanto e o nosso orgulho.

Neste dia, em que o Santo recebe a veneração dos crentes e a cidade se recama de galas, para solenizar o seu natal, justo é que clamemos pela conclusão do templo, consagrado ao seu padroeiro e destinado a testemunhar a perenidade 
de nossa crença, e a indestrutibilidade de nossa fé. E' preciso, é necessario, é indispensavel que, a breve trecho, exsurja a nossa Catedral, magestosa, no esguio das suas linhas impecaveis, triunfante, na ânsia de evolar-se até Deus,bela no seu conjunto arquitetônico, impressionante na severidade de suas figuras, cativante, na sugestiva doçura dos seus paineis; dominadora, no encanto irisante de seus vitraes, untuosa, na religiosidade dos seus mistérios, patriótica, nas iluminuras e nos seus motivos, nos adornos que embelezam o duro granito, que a informa, - símbolo de religião e de fé, mas tambem índice de nossa cultura e pàdrão de nossa arte.

A vida do Santo, que deu o seu nome à cidade nascida, no dia em que a Igreja o exalta, para bom anúncio do futuro, na expressão do seu primeiro cronista, é um dos exemplos mais impressionantes do que póde a União da fé e da vontade. Que a nossa fé e a nossa vontade se unam, para que o sonho do saudoso antístite d. LEOpoldo em breve se concretize, e que, dentro em pouco, o seu eminente sucessor possa entregar a Catedral, em definitivo, ao culto dos fieis, à veneração da cidade, que a ergueu, e à admiração de todo país. Porque as catedrais não são apenas demonstração de fé e de crença, têm tambem expressão histórica e artística, que as desligam do puro sentimento religioso, para as transformar em motivos de orgulho nacional. Cada pedra, cada bloco, cada estatua, cada florão, cada nave, cada vitral ou painel, representam hinos de fé, que se levantam até o Senhor, mas são-tambem sinfonias de glórias à cidade, que as erige e venera. E', pois, dever de todos contribuir, de bom ânimo, para a sua feitura, pobres e ricos, crentes ou não, correspondendo ao comovente apêlo do eminente arcebispo d. José Gagpar, disputando com fervor, o título, que ha de se tornar glorioso, de legionário da Catedral. E' um dever para com Deus, mas tambem uma obrigação para com a Pátria, e, na aliança desses dois 
nomes sublimes, que as catedrais simbolizam, está a fôrça que ha de vencer todos os obstáculos, como o Santo do dia, com a intrepidez da sua inteligência e a resistência da sua vontade, removeu e aluiu os que se antepunham à disseminação de sua crença e à vitoria da sua fé. Unamos os nossos esforços para a conclusão da Catedral, para honra de nossa terra e nossa gente e para que maior seja

La gloria di Colui che tutto muove. 